\title{
Effect of sex on ratios and concentrations of DNA and RNA in three marine species
}

\author{
M. Alexandra Chícharo*, Ana Amaral, Pedro Morais, Luis Chícharo \\ Universidade do Algarve, Faculdade de Ciências do Mar e do Ambiente (FCMA), Centro de Ciências do Mar (CCMAR), \\ Campus de Gambelas, 8005-139 Faro, Portugal
}

\begin{abstract}
The aim of the present study was to quantify differences in RNA:DNA ratios between male and female fish Pomatoschistus microps, crustaceans Crangon crangon, and bivalves Ruditapes decussatus. RNA:DNA ratios were greater in females than in males, especially because of a greater RNA content per unit dry weight in females. Sexual dimorphism in addition to physiological and behavioural differences between males and females may account for these results. RNA:DNA ratios of adult marine organisms should be interpreted with caution, because the effect of sex on nucleic acid concentrations may bias results if the sex ratio in the sample from which results were derived is not representative of the population.
\end{abstract}

KEY WORDS: RNA:DNA ratio $\cdot$ Sex $\cdot$ Pomatoschistus microps $\cdot$ Crangon crangon $\cdot$ Ruditapes decussatus Resale or republication not permitted without written consent of the publisher

\section{INTRODUCTION}

Condition indices are generally interpreted as indicators of tissue energy reserves, which characterize components of the environment in which organisms live (e.g. food and habitat availability, competition, predation, physical factors, and pollution) (Lloret \& Planes 2003). Since the first reports of the usefulness of RNA:DNA ratios for assessing growth rates and condition of fish (Bulow 1970), and subsequently of different marine organisms, e.g. bivalves (Wright \& Hetzel 1985) cephalopods (Clarke et al. 1989) and crustaceans (Rosa \& Nunes 2003), factors that may confound the results of such assays (e.g. size, life cycle stage [Bulow 1970], and diel variation [Chícharo et al. 1998]) have been identified. Bulow (1970) also indicated that temperature and maturation might have significant effects on levels of nucleic acids. To avoid the confounding effect of maturation, he recommended that only white muscle should be used in these analyses.

Several studies of the growth rates and conditions of aquatic organisms assumed no differences in nucleic acid content of muscle tissue or whole organisms between males and females, e.g. Regnault \& Luquet (1974), Wright \& Hetzel (1985), Paon \& Kenchington (1995), Chícharo et al. (2003), and Norkko et al. (2005). Nevertheless, the effect of sex on RNA:DNA ratios has not yet been investigated. Our aim was to quantify differences in white muscle RNA:DNA ratio, RNA $\mathrm{mg}^{-1}$ dry wt, and DNA $\mathrm{mg}^{-1}$ dry wt between male and female fish Pomatoschistus microps, crustaceans Crangon crangon, and bivalves Ruditapes decussatus. We selected species with different habitats, feeding habits, and stress conditions, and individuals at different maturation stages in order to negate the confounding effect of physiological, morphometric, and behavioural changes on differences in nucleic acid indices between males and females.

\section{MATERIALS AND METHODS}

Sample collection. The common goby Pomatoschistus microps and shrimp Crangon crangon were collected using a conical otter trawl net between January and April 2003 from the Guadiana Estuary near the 


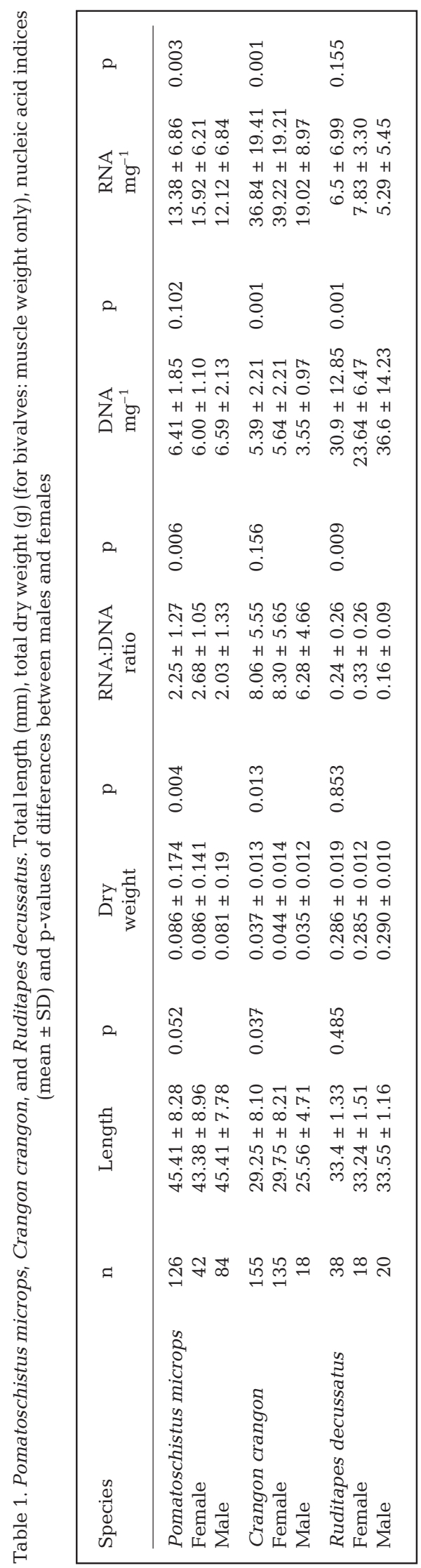

Castro Marim salt marshes. Sampling for the goby was conducted during the reproductive season, which is longer in Portugal than in northwest European waters and extends from December to April (Leitão et al. 2006), and for the shrimp during the post-spawning and resting period (M. A. Chícharo pers. obs.). Samples of the clam Ruditapes decussatus were bought at the local market during July 2003, the end of the spawning period of this species (Vilela 1947). Fish and shrimp were placed in liquid nitrogen immediately after collection, and sex identification was conducted at a later stage. Bivalves were kept alive until the sexes had been identified ( 1 to $2 \mathrm{~h}$ ) and were then stored in liquid nitrogen.

Laboratory analysis. Before specimens were freezedried, total lengths of fresh bivalves, thawed fish and shrimp were measured, and sex identification was conducted using a dissecting microscope. Nucleic acids were determined from a portion of white muscle, but total dry weight was determined for each individual. RNA and DNA content was analyzed according to fluorometric methods described by Esteves et al. (2000) and Chícharo et al. (2001).

Data analysis. Within-species effects of sex on indices derived from nucleic acid concentrations, on total dry weight and on total length of individuals were determined by 1-way ANOVA. Analysis of covariance (ANCOVA) was also performed with dry weight as a covariate. Because numbers of female and male Crangon crangon differed greatly, we had to reduce female number in ANCOVA. Female $C$. crangon size range was similar to that of males. To investigate the interaction between sampling dates and sex, we also ran a 2way ANOVA for C. crangon. All data analysis was conducted using STATISTICA 5 software.

\section{RESULTS}

Mean RNA:DNA ratios of male and female Pomatoschistus microps and Ruditapes decussatus differed significantly (Table 1). Mean RNA:DNA ratios of male and female Crangon crangon differed significantly when dry weight (which differed significantly between sexes) was included as a covariate in ANCOVA (Table 2). Correlations between RNA:DNA ratios and length were only significant for C. crangon $(\mathrm{r}=0.338$, $\mathrm{p}=0.028$ ).

RNA content also differed significantly between males and females. RNA concentrations ( $\mu \mathrm{g} \mathrm{mg}^{-1}$ dry wt) were greater in females than in males. DNA concentrations ( $\mu \mathrm{g} \mathrm{mg}^{-1}$ dry wt) were greater in males than in females except for Crangon crangon, in which DNA concentrations were greater in females than in males. When size effects were negated, the difference 
Table 2. ANCOVA results. (a) Pomatoschistus microps, (b) Crangon crangon, and (c) Ruditapes decussatus. Sex was the main effect and dry weight was a covariate

\begin{tabular}{|lrrcc|}
\hline (a) & MS effect & MS error & $F(1,2): 1,123$ & $\mathrm{p}$ \\
\hline RNA:DNA & 9.408 & 1.613 & 5.833 & 0.017 \\
DNA mg-1 & 10.064 & 3.568 & 2.821 & 0.096 \\
RNA mg $^{-1}$ & 263391 & 40.872 & 6.444 & 0.013 \\
& & & & \\
(b) & MS effect & MS error & $F(1,2): 1,86$ & $\mathrm{p}$ \\
\hline RNA:DNA & 219.33 & 26.031 & 8.426 & 0.005 \\
DNA mg & 49.34 & 3.093 & 15.954 & 0.0001 \\
RNA mg & 14348.21 & 283.674 & 50.58 & 0.0001 \\
& & & & \\
(c) & MS effect & MS error & $F(1,2): 1,35$ & $\mathrm{p}$ \\
\hline RNA:DNA & 0.198 & 0.026 & 7.687 & 0.008 \\
DNA mg & 1414.471 & 124.920 & 11.323 & 0.001 \\
RNA mg & 370.111 & 23.905 & 15.486 & 0.022 \\
\hline
\end{tabular}

Table 3. Crangon crangon. Two-way ANOVA results from nucleic acid-derived indices (RNA:DNA, RNA $\mathrm{mg}^{-1}$, DNA $\mathrm{mg}^{-1}$ ) in which sex and sampling month were main effects and dry weight was a covariate

\begin{tabular}{|lccccc|}
\hline & Wilks' $\lambda$ & Rao's $R$ & df 1 & df 2 & $p$ \\
\hline Sex & 0.755 & 8.845 & 3 & 82 & 0.0001 \\
Sampling month & 0.933 & 1.948 & 3 & 82 & 0.128 \\
Interaction & 0.976 & 0.672 & 3 & 82 & 0.572 \\
\hline
\end{tabular}

in DNA concentration between sexes of C. crangon was not significant, in contrast to that observed for Pomatoschistus microps (Table 2).

As the results in Table 3 demonstrate, the effect of sampling month (only available for Crangon crangon) was not significantly important when compared with the effect of sex.

\section{DISCUSSION}

Mean RNA:DNA ratios of females tended to be greater than those of males in all 3 species studied, largely owing to greater RNA concentrations. Analysis of pooled data did not reveal any feature common to all 3 species. This result was expected, because nuclear DNA content varies considerably among organisms of similar structural complexity and because repetitive DNA sequences mean that the size of the genome is not related to structural complexity in organisms of higher evolutionary status (Levin 1994). For example, the minimum nuclear DNA content of crustaceans is $0.35 \mathrm{pg}$ and that of fish is $0.39 \mathrm{pg}$, but the minimum content of bivalves is $1.36 \mathrm{pg}$ (Fonseca et al. 2000). In our study, DNA concentrations of bivalves were also greater than those of the other species. Because DNA concentrations differed among species, discussion of results is restricted to within-species. Our results may have derived from sexual dimorphism, physiological or biochemical differences between sexes, or behavioural differences between sexes.

Sexual dimorphism is usually expressed as differences in the sizes of males and females. Sexual dimorphism was observed in fish and shrimp but not in bivalves, even though there were significant differences between sexes with regard to indices derived from bivalve nucleic acid concentrations. Differences
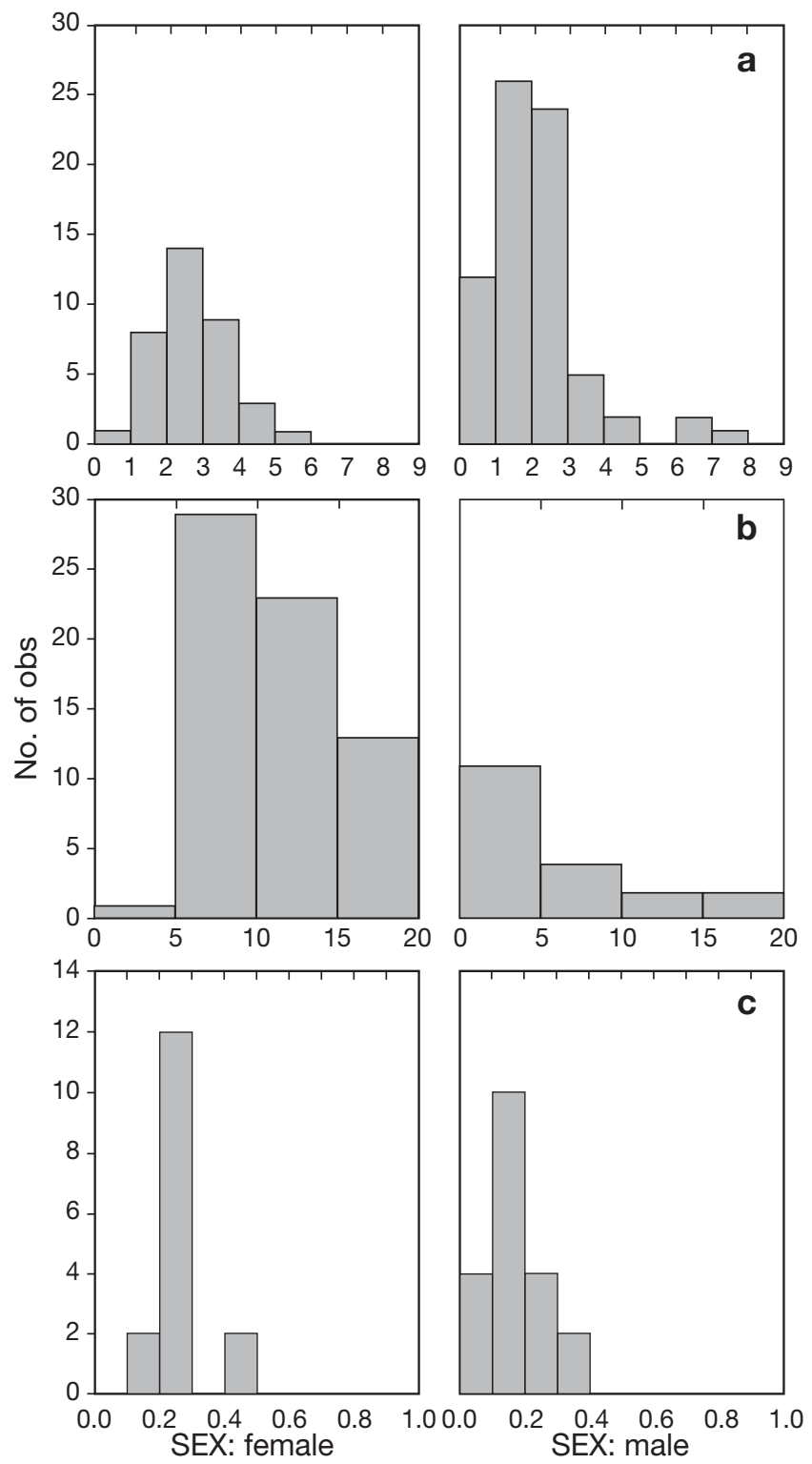

Fig. 1. RNA:DNA ratio histogram of male vs. female (a) Pomatoschistus microps, (b) Crangon crangon, and (c) Ruditapes decussatus 
between males and females were detected even when female size was significantly less than that of males, e.g. as in Pomatoschistus species. Differences in DNA content between males and females were small and no common trend was detected among the studied species. In contrast, RNA content of females was greater than that of males in all 3 species. The DNA content of an organism may change during growth, depending on whether increased weight or size is caused by hyperplasia or hypertrophy. Variation within a species is usually low, because identical genomes contain identical quantities of nuclear DNA. Nevertheless, the total amount of DNA in a defined amount of dry tissue will depend on cell size, which changes with age, stage of the reproductive cycle, and nutritional status (Regnault \& Luquet 1974). RNA concentrations depend on factors that affect cell size, and are usually more variable than DNA concentrations because RNA is required for protein synthesis, which responds quickly to changes in environmental conditions (Bulow 1970). According to Justo et al. (2005), mitochondria and protein content are also greater in female rats than in males.

Our results may have derived from physiological or biochemical factors. Maturation and reproduction, which differ between males and females, often require different amounts of energy, as discussed by Paon \& Kenchington (1995) and Pérez Camacho et al. (2003). According to these authors, reproductive costs are much greater for females than for males, which implies that protein synthesis and therefore RNA content is greater in females than in males. The clam Ruditapes decussatus (Pérez Camacho et al. 2003) exhibits clear sexual differentiation in biochemical composition. Nutritional stress results in a moderate degree of organic weight loss in clams, but protein and lipid levels remain constant in females. The results of these previous studies highlight the importance of protein synthesis for females, especially during spawning activity, which could explain the higher RNA content and RNA:DNA ratios of female bivalves observed in our study. However, this is not only restricted to spawning period: Crangon crangon was analysed after spawning and in the resting period, and greater RNA content and RNA:DNA ratios were still evident in females.

Behaviour could also lead to differences in RNA/ DNA ratios between sexes. The higher RNA:DNA ratios of female Pomatoschistus microps could be a consequence of differences in the activity patterns of sexes, because parental care is supported by males (Salgado et al. 2004). According to Salgado et al. (2004), males are probably limited to foraging for food available around the nest during the breeding season, whereas females behave as food maximizers, feeding on a greater number of taxa and ingesting most prey types in higher numbers. However, this argument cannot be extended to account for the higher condition of females than males in the other species studied, because these species do not exhibit male parental care. Female parental care occurs in Crangon crangon, but this does not limit the ability of females to search for food because their eggs are carried in pleopods. Ruditapes decussatus exhibited the lowest RNA:DNA ratios, indicating very poor condition $(<1$, see Chicharo et al. 2001), but the general pattern of low values for males and high values for females in terms of RNA concentrations and RNA:DNA ratios was still observed.

In conclusion, caution is needed when interpreting RNA:DNA ratio data from adult organisms, because sex differences in nucleic acid concentrations bias RNA indices if the frequencies of sexes in samples are not representative of those in the population. Samples in which males are over-represented result in an underestimate of the condition of the population, and those in which females are over-represented result in an overestimate.

Acknowledgements. This research was partially funded by the ERIC (FCT/P/MAR/15263/1999) and GUADIRIA projects (POCTI/BIA-BDE/59200/2004), and by PhD grant to P.M. (SFRH/BD/5187/2001). A. Morais and M. Skora are thanked for help with sampling and laboratory processing.

\section{LITERATURE CITED}

Bulow FJ (1970) RNA-DNA ratios as indicators of recent growth rates of a fish. J Fish Res Board Can 27:2343-2349

Chícharo LMZ, Chícharo MA, Alves F, Amaral A, Pereira A, Regala J (2001) Diel variation of the RNA:DNA ratios in Crassostrea angulata (Lamarck) and Ruditapes decussatus (Linnaeus 1758) (Mollusca: Bivalvia). J Exp Mar Biol Ecol 259:121-129

Chícharo MA, Chícharo L, López-Jamar E, Valdes L, Ré P (1998) Estimation of starvation and diel variation of the RNA:DNA ratios of field caught Sardina pilchardus larvae off the north of Spain. Mar Ecol Prog Ser 164:273-283

Chícharo MA, Chícharo L, Amaral A, Condinho S, Gaspar M (2003) Chronic effects of dredging-induced stress on the clam (Spisula solida): nucleic acid and lipid composition. Fish Res 63:447-452

Clarke A, Rodhouse PG, Holmes LJ, Pascoe PL (1989) Growth rate and nucleic acid ratio in cultured cuttlefish Sepia officinalis (Mollusca: Cephalopoda). J Exp Mar Biol Ecol 133:229-240

Esteves E, Chícharo MA, Pina T, Coelho ML, Andrade JP (2000) Comparison of RNA:DNA ratios obtained with two methods for nucleic acid quantification in gobiid larvae. J Exp Mar Biol Ecol 245:43-55

Fonseca J, Marques JC, Paiva A, Freitas A, Madeira V, Jørgensen S (2000) Nuclear DNA in the determination of weighting factors to estimate exergy from organisms biomass. Ecol Model 126:179-189

Justo R, Frontera M, Pujol E, Rodríguez-Cuenca S, Lladó I, 
García-Palmer F, Roca P, Gianotti M (2005) Genderrelated differences in morphology and thermogenic capacity of brown adipose tissue mitochondrial subpopulations. Life Sci 76:1147-1158

Leitão R, Martinho F, Neto JM, Cabral H, Marques J, Pardal MA (2006) Feeding ecology, population structure and distribution of Pomatoschistus microps (Krøyer, 1838) and Pomatoschistus minutus (Pallas, 1770) in a temperate estuary, Portugal. Estuar Coast Shelf Sci 66:231-239

Levin B (1994) Genes V. Oxford University Press, Oxford

Lloret J, Planes S (2003) Condition, feeding and reproductive potential of white seabream Diplodus sargus as indicators of habitat quality and the effect of reserve protection in the northwestern Mediterranean. Mar Ecol Prog Ser 248: 197-208

Norkko J, Pilditch CA, Thrush SF, Wells RMG (2005) Effects of food availability hypoxia on bivalves: the value of using multiple parameters to measure bivalve condition in environmental studies. Mar Ecol Prog Ser 298:205-218

Paon LA, Kenchington ELR (1995) Changes in somatic and reproductive tissues during artificial conditioning of the

Editorial responsibility: Howard Browman (Associate Editorin-Chief), Storebø, Norway sea scallop, Placopecten magellanicus (Gmelin, 1791). J Shellfish Res 14:53-58

Pérez Camacho A, Delgado M, Fernández-Reiriz MJ, Labarta U (2003) Energy balance, gonad development and biochemical composition in the clam Ruditapes decussatus. Mar Ecol Prog Ser 258:133-145

Regnault M, Luquet P (1974) Study by evolution of nucleic acid content of prepubertal growth in the shrimp Crangon vulgaris. Mar Biol 25:291-298

Rosa R, Nunes A (2003) Seasonal changes in nucleic acids, amino acids and protein content in juvenile Norway lobster (Nephrops norvegicus). Mar Biol 143:565-572

Salgado JP, Cabral HN, Costa MJ (2004) Feeding ecology of Pomatoschistus minutus (Pallas, 1770) and Pomatoschistus microps (Krøyer, 1838) in the upper Tagus estuary. Sci Mar 68:425-434

Vilela H (1947) Contribuição para o estudo das comunidades animais dos parcéis da Ria de Faro. Arq Mus Bocage Nova Ser 18:97-164

Wright DA, Hetzel EW (1985) Use of RNA:DNA ratios as an indicator of nutritional stress in the American oyster Crassostrea virginica. Mar Ecol Prog Ser 25:199-206

Submitted: May 4, 2006; Accepted: August 14, 2006 Proofs received from author(s): February 14, 2007 